\title{
AGRONOMICAL CHARACTERIZATION OF MINORITY GRAPEVINE CULTIVARS FROM ASTURIAS (SPAIN)
}

\author{
CARACTERIZAÇÃO AGRONÓMICA DE CULTIVARES MINORITÁRIAS DE VIDEIRA DAS \\ ASTÚRIAS (ESPANHA)
}

\author{
Maria Dolores Loureiro*, Paula Moreno-Sanz, Bélen Suárez
}

\begin{abstract}
Servicio Regional de Investigación y Desarrollo Agroalimentario (SERIDA), Área de Tecnología de los Alimentos, Apdo, 13. 33300 Villaviciosa, Asturias, Spain.
\end{abstract}

*corresponding author: Tel.: +34 9858900 66, e-mail: mdolorlr@serida.org

(Received 14.02.2017. Accepted 29.08.2017)

SUMMARY

Grapevine (Vitis vinifera L.) was an important crop in the past in Asturias (Northwestern Spain), but the phylloxera and later the boom of the mining industry almost led to its extinction in the last century. Currently, the grape growers are rescuing the old cultivars present in the region from ancient times, but the long period of abandon has originated a lack of information about their characteristics. Four red ('Albarín Negro', 'Carrasquín', 'Verdejo Negro' and 'Mencía') and two white ('Albarín Blanco' and 'Godello') minority grapevine cultivars from Asturias (Spain) were studied for phenology, fertility, vigor, production and berry quality parameters for two consecutive years. Great differences between cultivars were found: 'Verdejo Negro' and 'Albarín Blanco' had an early budburst both years, 'Carrasquín' was the latest harvested, and 'Albarín Negro' presented the highest total fertility. 'Mencía' had the greatest bunch weight, and, together with 'Verdejo Negro', the lowest total acidity and highest pH. Shikimic acid was a varietal marker, its content being higher in 'Carrasquín', 'Verdejo Negro' and 'Albarín Blanco'. Significant differences between years in the measured parameters were also found. Agronomical evaluation is the first step to recover these minority cultivars from extinction and to provide to grape growers a deeper knowledge about the characteristics of each cultivar, allowing enriching and diversifying the wine market with different products.

\section{RESUMO}

A videira (Vitis vinifera L.) era uma cultura importante no passado nas Astúrias (Noroeste da Espanha), mas a filoxera e mais tarde o "boom” da indústria de mineração quase levou à sua extinção no século passado. Atualmente, os viticultores estão resgatando as cultivares antigas presentes na região desde tempos remotos, mas o longo período de abandono originou a falta de informações sobre as suas características. Foram estudadas quatro cultivares minoritárias tintas ('Albarín Negro’, 'Carrasquín’, 'Verdejo Negro’ e 'Mencía’) e duas cultivares minoritárias brancas ('Albarín Blanco' e 'Godello') das Astúrias (Espanha) relativamente à fenologia, fertilidade, vigor, produção e qualidade de frutos durante dois anos consecutivos. Verificaram-se grandes diferenças entre as cultivares: 'Verdejo Negro' e 'Albarín Blanco' tiveram um abrolhamento precoce nos dois anos, ‘Carrasquín' foi o colhido mais tarde, e ‘Albarín Negro’ apresentou a maior fertilidade total. 'Mencía’ teve o maior peso de cacho e, juntamente com 'Verdejo Negro', a menor acidez total e maior pH. O ácido chiquímico revelou-se um marcador varietal, sendo o seu teor maior em 'Carrasquín', 'Verdejo Negro’ e ‘Albarín Blanco'. Também foram encontradas diferenças significativas entre os anos nos parâmetros medidos. A caraterização agronómica é o primeiro passo para recuperar estas cultivares minoritárias da extinção e proporcionar aos viticultores um conhecimento mais aprofundado das características de cada cultivar, permitindo enriquecer e diversificar o mercado do vinho com diferentes produtos.

Key words: Vitis vinifera L., phenology, fertility, production, shikimic acid, berry quality.

Palavras-chave: Vitis vinifera L., fenologia, fertilidade, produção, ácido chiquímico, qualidade da uva.

\section{INTRODUCTION}

The prospection, recovery and study of minority grapevine cultivars are of capital importance to preserve the genetic resources of a region from extinction. Phylloxera plague at the end of XIX century, later the boom of international cultivars and, at present, the restrictions in the number of cultivars allowed in every designation of origin has caused the disappearance of a great number of cultivars

This is an Open Access article distributed under the terms of the Creative Commons Attribution License

(http://creativecommons.org/licenses/by/4.0), which permits unrestricted use, distribution, and reproduction in any medium, provided the original work is properly cited. 
worldwide. New challenges for the viticulture such as the climate change, which is originating wines with low acidity and high alcohol content, and the emerging diseases and plagues, made imperative the conservation of the existing cultivars to dispose of a broad genetic pool to face these new threats maintaining the quality and diversity of wines. Moreover, the great competence in the wine market is promoting the elaboration of distinct wines, trying to put the emphasis on the exclusiveness of the cultivars and terroirs, looking for a market niche. As a consequence, the countries with a long tradition in the culture of grapevine are currently recovering and characterizing autochthonous cultivars, nearly extinct in some cases, as potential producers of quality wines. In Greece, Mattheou et al. (1995a,b) characterized for agronomical parameters 41 table grape cultivars of the Vitis Germplasm Bank, and Merkouropoulos et al. (2015) studied the anthocyanins, the phenolic content and the berry parameters of 91 Greek cultivars. In Italy, Iorizzo et al. (2014) evaluated the wines from Tintilia, and Milella et al. (2016) the polyphenolic profile of 10 autochthonous Italian cultivars. Albuquerque et al. (2006) analyzed the agronomical and berry parameters of red Spanish cultivars, Maletic et al. (2009) the anthocyanins of cultivars from Croatia, and Dobrei et al. (2015) the agronomical and enological parameters of Romanian cultivars. The agronomical and enological evaluation of every cultivar is necessary to establish its potential to produce a quality wine in a specific region. This evaluation includes the study of the phenology, the vegetative development, production parameters, and quality of berry, must and wine. Phenology of grapevine depends on the climate, the geographical location and the cultivar (Jones and Davis, 2000), and this knowledge is paramount to select the more suitable cultivars to plant in a specific location, the management practices to use, the programming of phytopathological treatments, and to develop predictive models for harvest date. The study of the vegetative development allows determining if a vine is balanced, which is primordial to obtain a berry of quality. The production parameters allow to predict yield and to decide the type of pruning to perform, whereas the berry parameters define the winemaking potential of a cultivar.

Grapevine is an old crop in Asturias (Northwestern Spain), first references dating back to 781 (Cortizo et al., 2008). The maximum extension of this crop occurred in mid-19 $9^{\text {th }}$ century with 5,493 ha (Feo, 1986). The drastic loss of surface until the presentday 100 ha was the consequence of the phylloxera plague, the expansion of coal-mining activities and the migration of rural population to the cities. In recent years grape growers are making efforts to restore Asturian vineyards, being recognized the Cangas Quality Wine appellation in 2008 (BOPA, 2008), and recently the Protected Designation of Origin Cangas. Most of vineyards are old, disposed in steep slopes, with a broad mixture of cultivars; the most extended are 'Albarín Negro', 'Carrasquín', 'Verdejo Negro', 'Mencía’, 'Albarín Blanco’ and, in a minor extension, 'Godello', most of them considered autochthonous of Northwestern Spain. 'Verdejo Negro' is also cultured in Portugal under the name of 'Bastardo', and as 'Trousseau Noir' in France; 'Godello' as 'Gouveio', 'Mencía' as 'Jaen', and 'Albarín Negro' as 'Alfrocheiro Preto' in Portugal, this latter cultivar having been stated as the parental of a great number of cultivars, representing together with their progenies around $15 \%$ of the grapevine extension of this country (Martín et al., 2011; Cunha et al., 2015). The new plantations are focused on 'Albarín Blanco' and 'Verdejo Negro', these preferences being based on the day to day experience of the grape growers and winemakers. The studies on the agronomical and enological characteristics of these cultivars are scarce, and most of them restricted to neighboring regions with different edafoclimatic conditions (Losada and Pariente, 1998; Orriols et al., 2004; Blanco et al., 2007; Vilanova et al., 2009). Concerning studies on Asturian vineyards, Hernáez et al. (2000) analyzed global parameters in musts and wines from 'Albarín Negro', 'Carrasquín' and 'Verdejo Tinto'; Loureiro and Suárez $(2006,2007)$ studied production, vigor and berry parameters of 'Albarín Negro', 'Carrasquín', 'Mencía', 'Verdejo Negro', 'Godello' and 'Albarín Blanco'. Gago et al. (2009) compared the ampelographical parameters, yield, probable alcoholic content, total acidity and $\mathrm{pH}$ of 'Albarín Blanco' cultivated in Asturias and in the adjacent region of Galicia. Loureiro et al. (2016) evaluated the effect of five rootstocks on the agronomical and enological performances of 'Albarín Negro'.

Considering the partial unawareness about the characteristics of the most widely spread cultivars of the Asturian region, their expansion in the last years, and that its wines are being awarded worldwide (www.cervim.org, www.catavinum.net), the agronomical and enological parameters of 'Albarín Negro', 'Carrasquín', 'Verdejo Negro', 'Mencía', 'Albarín Blanco' and 'Godello' were evaluated for two consecutive years in this study. This is the first step to characterize them to reach their best management and exploitation aiming at obtaining the best quality of wines. 


\section{MATERIAL AND METHODS}

Experimental design and edaphoclimatic
characterization:

Four red ('Albarín Negro’, 'Carrasquín', 'Mencía’ and 'Verdejo Negro', respectively referred to as 'Alfrocheiro'/277, 'Carrasquín'/2123, 'Mencía'/7623 and 'Trousseau noir'/12668 at the VIVC) and two white cultivars ('Albarín Blanco' and 'Godello', referred to as 'Albarín Blanco'/22838 and 'Gouveio'/12953) were studied. Data were taken from 40 vines of each cultivar distributed in four repetitions each of 10 vines, for two consecutive years (2008-2009). The study of the cultivars was performed in the borough of Cangas del Narcea, in vineyards in close proximity, with similar cultural and environmental conditions (Figure 1). 'Albarín Negro' and 'Mencía' were in an old vineyard (about 80 years old), while the other vineyards were younger (around 10 years old). All the vines were conducted in double cordon, formed of three spurs with two buds each one per arm (Table I). Samples of soil of the four plots were collected and analyzed for granulometry, organic matter, assimilable elements, $\mathrm{pH}$ and electric conductivity.

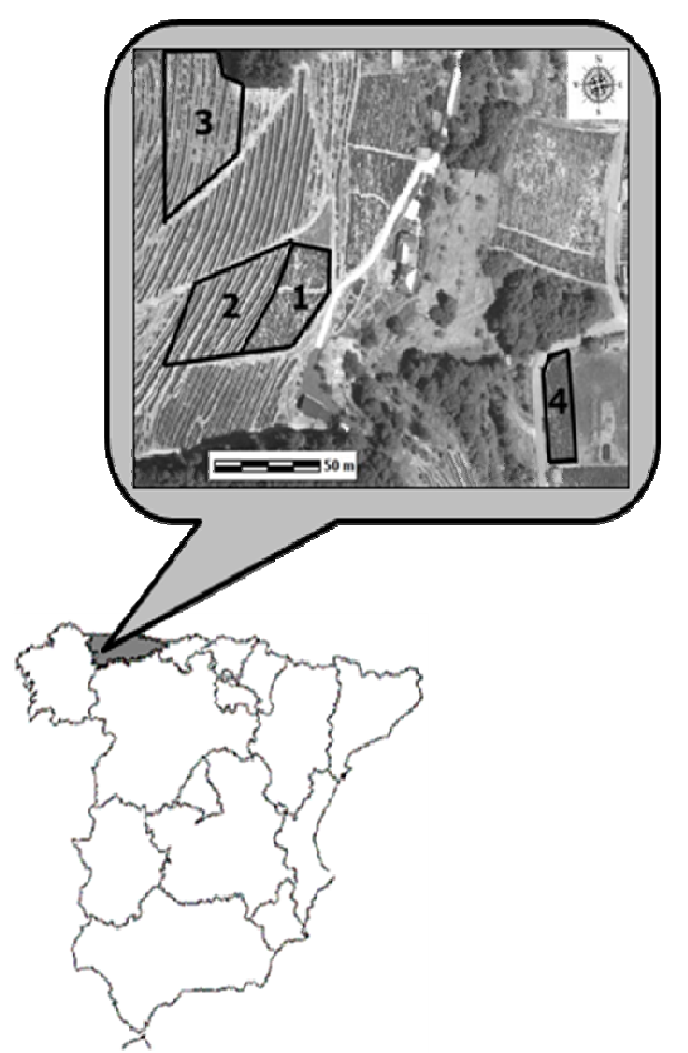

Figure 1. Situation of the plots. Situação das parcelas.
Table I

Characteristics of the vineyards Características das vinhas

\begin{tabular}{|c|c|c|c|c|}
\hline & Plot 1 & Plot 2 & Plot 3 & Plot 4 \\
\hline Cultivars & $\begin{array}{l}\text { Albarín } \\
\text { Negro - } \\
\text { Mencía }\end{array}$ & $\begin{array}{c}\text { Verdejo } \\
\text { Negro - } \\
\text { Carrasquín }\end{array}$ & Godello & $\begin{array}{c}\text { Albarín } \\
\text { Blanco }\end{array}$ \\
\hline Rootstock & $\begin{array}{l}\text { Rupestris } \\
\text { de Lot }\end{array}$ & 110 Richter & $\begin{array}{c}110 \\
\text { Richter }\end{array}$ & $\begin{array}{c}110 \\
\text { Richter }\end{array}$ \\
\hline $\begin{array}{l}\text { Age of vineyard } \\
\text { (years) }\end{array}$ & 80 & 10 & 7 & 8 \\
\hline Elevation (m) & 460 & 483 & 491 & 404 \\
\hline Area $\left(\mathrm{m}^{2}\right)$ & 1,431 & 1,546 & 1,270 & 230 \\
\hline $\begin{array}{l}\text { Between-rows } \\
\text { distance (m) }\end{array}$ & $1.0-1.2$ & 2.7 & 2.5 & 1.3 \\
\hline $\begin{array}{l}\text { Within-row vine } \\
\text { spacing }(\mathrm{m})\end{array}$ & $1.0-1.2$ & 1.0 & 1.0 & 1.0 \\
\hline $\begin{array}{l}\text { Canopy width } \\
\text { (cm) }\end{array}$ & 10.7 & 11.7 & 10.2 & 11.2 \\
\hline Canopy height (m) & 0.9 & 1.0 & 1.0 & 1.0 \\
\hline $\begin{array}{l}\text { Planting density } \\
\text { (vines/ha) }\end{array}$ & 8,264 & 3,704 & 4,000 & 7,692 \\
\hline $\begin{array}{l}\text { Canopy surface } \\
\text { area }\left(\mathrm{m}^{2} / \mathrm{ha}\right)\end{array}$ & 17,062 & 8,345 & 9,315 & 14,539 \\
\hline
\end{tabular}

\section{Phenology}

Phenological data of stages C (budburst), I (flowering), $\mathrm{M}$ (veraison), $\mathrm{N}$ (harvest) and $\mathrm{P}$ (leaf fall) were monitored according to the Baggiolini phenological scale (1952). The date of full stage was established when $50 \%$ of the organs were in this stage (OIV, 2008). Dates are expressed in number of days passed from $1^{\text {st }}$ March.

\section{Sprouting percentages and fertility}

The following parameters were studied following the methodology of the Viticulture Research Group of the Technical University of Madrid (http://ocw.upm.es/produccion-

\section{vegetal/viticultura/contenidos/Practicas/05desborre.p} df):

Sprouting percentage, Global sprouting percentage, Sprouting percentage of the secondary buds in spurs, Potential fertility of the spurs, Potential fertility of the shoots from basal buds, Potential fertility of watersprouts, Total potential fertility, Real fertility of the spurs, Real fertility of the shoots from basal buds, Real fertility of watersprouts and Total real fertility (definitions are provided in Supplementary material). The sprouting data were taken in April and fertility data in July - August.

\section{Production and vigor}

Bunches of every kind of shoot (from spurs, basal buds and watersprouts) were weighed separately for every vine and the average production and weight of bunch were calculated. The average weight of the model bunch of each cultivar was also measured as 
the average of the weight of 10 typical bunches from bud counts, and the vegetative development by the pruning wood weight. The vegetative equilibrium of each vine was assessed through the Ravaz index, defined as the ratio yield/pruning wood weight (Smart and Robinson, 1991).

\section{Quality parameters of the berry}

The following parameters were determined from 500 mature grapes at harvest: berry weight, total soluble solids ( ${ }^{\circ}$ Brix), $\mathrm{pH}$, total acidity and organic acids (tartaric, malic, citric and shikimic acids). Total soluble solids were determined through electronic density meter (Anton Paar - DMA 5000); pH and total acidity following the methodology of the OIV (http://www.oiv.int/); and organic acids by HPLCDAD according to Picinelli et al. (2000).

\section{Statistical analysis}

ANOVA analysis was performed to all the parameters. A Duncan test or, when unequality of variances, a Games-Howell test, was carried out.

A stepwise discriminant analysis was also done taking into account all the experimental data. Ravaz index and real fertilities were previously eliminated as they were highly correlated with other variables. The final data matrix was constructed with 48 objects (six cultivars by four repetitions by two years) and 26 variables (budburst, veraison, harvest and leaf fall dates; sprouting, global sprouting and secondary buds sprouting percentages; potential fertility of spurs, basal buds and watersprouts; total potential fertility; average weight of bunches from spurs, basal buds and watersprouts; production of spurs, basal buds and watersprouts; total production per vine; pruning wood weight; weight of 100 berries, ${ }^{\circ}$ Brix, total acidity, and tartaric, malic, citric and shikimic acids). Variables were elected by minimizing the lambda of Wilks, at a $90 \%$ confidence level. The analyses were performed with the SPSS v.12.0. software.

\section{RESULTS AND DISCUSSION}

Most of the Asturian vineyards are old, cultured in steep slopes, without forming terraces, with an extension of less than 1 ha, different spacing between vines and charges at pruning, and a broad mixture of cultivars into a same vineyard, with the subsequent problems to harvest at the optimal ripening point. In the last ten years new vineyards are being planted in terraces, grouping the plants by cultivar.
Plots of this study were selected because they were close each other, their mesoclimate homogeneity (slope, exposition and elevation) and the existence of a sufficient number of plants of each cultivar to establish comparisons among them. Type of pruning, cultivation practices and phytosanitary treatments were also similar. Unfortunately, as distinguishing features, the plants of 'Mencía' and 'Albarín Negro' cultivars were older and grafted in a different rootstock, and the planting density and nutritional parameters of soil were different among vineyards (Tables I and II). All the plots presented a sandy-loam texture, a low pH (excepting the plot 4), and important differences in the assimilable elements. Vineyard 3 had the lowest levels of organic matter, potassium, phosphorous and ratio carbon/nitrogen. Levels of phosphorous were high in vineyards 1 and 4 , possibly because of the repetitive use of mineral fertilizers. Cation exchange capacity was low, excepting plot 4 (Table II). It was not possible to find all the cultivars in the same conditions or in a single vineyard, so these features must be taken into account when interpreting the results of this study.

This viticole region is assigned to the climatic region I, where "hillside slopes and valley areas of moderate productivity are available for vines. The early maturing premium quality dry table wine varieties attain their best development here" (Winkler et al, 1974). In the active period, the average temperatures oscillate between $15^{\circ} \mathrm{C}$ and $17^{\circ} \mathrm{C}$, and the rainfall between 400 and $600 \mathrm{~mm}$, the summer rainfall ranging between $100 \mathrm{~mm}$ in dry years and more than $200 \mathrm{~mm}$ in rainy years. Phenological data are exposed on Table III. Budburst occurred between the end of March and beginning of April. The time passed between the first cultivar's budburst and the last cultivar's budburst was eight days longer in 2009 than in 2008, due to an important drop of the temperature in the last days of March and beginning of April 2009 (average daily temperatures between $3-6{ }^{\circ} \mathrm{C}$ for five days) once the budburst of the earliest cultivars had started. 'Godello' had an erratic budburst, being the latest cultivar in 2008 and the earliest in 2009. Concerning the other cultivars, 'Verdejo Negro' and 'Albarín Blanco' had the earliest budburst both years, being 'Mencía' the most delayed. Considering the climate of this region, cultivars with a late budburst would be advisable because of risk of frost.

Flowering took place in the second half of June both years. In the control of the $18^{\text {th }}$ June 2009 flowering had not started, but in the next control (23 $3^{\text {th }}$ June) all the plants were in full flowering, so that the $21^{\text {th }}$ June was taken as the date of full stage $(50 \%$ of open flowers) for all the cultivars. Veraison occurred the 
second half of August; 'Carrasquín' being the most delayed. The flowering-veraison period was shorter in 2009 for all the cultivars excepting 'Carrasquín' and 'Godello'. Harvest took place the first half of October, 'Carrasquín’ ripening the latest both years. This cultivar is always picked one or two weeks after the others in the region; despite the disadvantage of its late maturation, it has a high resistance to botrytis, being harvested in optimal conditions. The conservation and study of cultivars with late ripening is essential in the current context of climatic change, as genetic resources able to produce wines with an adequate balance between sugar and acids in the future.

\section{Table II}

Edaphological analysis of every plot Análise de solo de cada parcela

\begin{tabular}{|c|c|c|c|c|}
\hline & Plot 1 & Plot 2 & Plot 3 & Plot 4 \\
\hline Cultivars & $\begin{array}{l}\text { Albarín } \\
\text { Negro- } \\
\text { Mencía }\end{array}$ & $\begin{array}{c}\text { Verdejo } \\
\text { Negro- } \\
\text { Carras- } \\
\text { quín }\end{array}$ & Godello & $\begin{array}{l}\text { Albarín } \\
\text { Blanco }\end{array}$ \\
\hline Texture & $\begin{array}{l}\text { Sandy- } \\
\text { loam }\end{array}$ & $\begin{array}{l}\text { Sandy- } \\
\text { loam }\end{array}$ & $\begin{array}{l}\text { Sandy- } \\
\text { loam }\end{array}$ & $\begin{array}{l}\text { Sandy- } \\
\text { loam }\end{array}$ \\
\hline Organic matter (\%) & 2.79 & 3.43 & 2.56 & 3.43 \\
\hline Total Nitrogen (\%) & 0.09 & 0.11 & 0.09 & 0.17 \\
\hline Carbon/Nitrogen & 7.06 & 8.1 & 5.85 & 8.05 \\
\hline Sodium (cmol/kg) & $<0.10$ & $<0.10$ & $<0.10$ & $<0.10$ \\
\hline Calcium (cmol/kg) & 0.98 & 2.76 & 5.51 & 11.99 \\
\hline Magnesium (cmol/kg) & 0.39 & 0.59 & 2.14 & 1.70 \\
\hline Potassium (mg/kg) & 136 & 204 & 94 & 167 \\
\hline $\begin{array}{l}\text { Phosphorous (Olsen) } \\
\text { (mg/kg) }\end{array}$ & 40 & 27 & 13 & 54 \\
\hline $\begin{array}{l}\text { Effective cation } \\
\text { exchange capacity } \\
(\mathrm{cmol}+/ \mathrm{kg})\end{array}$ & 5.23 & 5.84 & 8.81 & 14.17 \\
\hline $\mathrm{pH}$ & 4.91 & 5.39 & 5.86 & 6.84 \\
\hline $\begin{array}{l}\text { Electrical conductivity } \\
(\mathrm{dS} / \mathrm{m})\end{array}$ & 0.075 & 0.065 & 0.045 & 0.170 \\
\hline
\end{tabular}

Muñoz et al. (2010) also studied the phenology of 'Albarín Blanco', 'Carrasquín’, 'Godello', 'Mencía' and 'Merenzao' (synonym of 'Verdejo Negro'), maintained in the Germplasm National Bank of El Encín (Madrid), with a continental Mediterranean climate, different from the Mediterranean-Oceanic climate of Cangas del Narcea. In their study, the earliest cultivars were 'Albarín Blanco' at budburst, 'Mencía' at veraison; and 'Carrasquín', 'Mencía' and 'Merenzao' at maturation; 'Albarín Blanco' and
'Godello' presented a medium date of maturity. The instability in the phenology of some cultivars ('Carrasquín' is the latest to ripen in Asturias) may be a consequence of the region where they are cultivated; as an example, 'Riesling' ripens earlier than 'Shyraz' in warm regions, and later in cool regions (Boulton et al., 1999; Dry and Coombe, 2004).

Leaf fall occurred the second half of November. 'Godello' was the latest cultivar to reach this phenological stage. With regard to the duration of the life cycle, no significant differences were observed among cultivars grown in the same plot ('Albarín Negro'-“Mencía”, and 'Carrasquín'-’Verdejo Negro'). Cultivars of the oldest plot, 'Albarín Negro' and 'Mencía', showed the shortest cycle both years; also presented the shortest period from budburst to harvest of all the red cultivars in 2008, and the shortest in 2009 when comparing all the cultivars. Besides the influence of the cultivar and the age of vineyard, it is important to take into account the effect of the rootstock, because these two cultivars were grafted in Rupestris de Lot, and the other cultivars in 110 R. In this regard, Loureiro et al. (2016) found significant differences in phenology in function of the rootstock for 'Albarín Negro', the period budburstmaturation being 6-13 days shorter in 'Rupestris de Lot' compared to $110 \mathrm{R}$. All the red cultivars shortened their cycle in 2009 when comparing to 2008, this shortening being more pronounced in the old vineyard (Table III).

In 2009, the drop of temperature at budburst produced an important effect on the sprouting. In these days, the cultivars with the earliest budburst ('Verdejo Negro', 'Albarín Blanco' and 'Godello') were in full $\mathrm{C}$ stage and presented the lowest sprouting percentages. 'Carrasquín' had begun budburst in these dates too, and a decrease of sprouting percentage can also be seen when comparing with 2008. The high percentage of global sprouting indicates that for all the cultivars, in addition to the bud counts, basal buds and/or watersprouts also sprouted. This increase was significantly higher in 2009 compared to 2008, with the exception of 'Albarín Blanco' that decreased. It has been stated that, when the bud counts are affected due to frost periods or other phenomena, the sprouting of other types of buds, as secondary and basal buds and watersprouts, is favoured (Huglin and Schneider, 2003). In fact, all the cultivars excepting 'Albarín Blanco', suffered an important increase in the sprouting of the secondary buds in 2009 (Table IV). 
Table III

Phenological data. Days from the $1^{\text {st }}$ of March

Dados fenológicos. Dias a partir de 1 de Março

\begin{tabular}{|c|c|c|c|c|c|c|c|}
\hline Phenological stage & Year & Albarín Negro & Mencía & Carrasquín & Verdejo Negro & Godello & Albarín Blanco \\
\hline \multirow[b]{2}{*}{ Stage C (Budburst) } & 2008 & $33.6^{\mathrm{b}}$ & $34.1^{\mathrm{b}, \mathrm{c}}$ & $34.0^{\mathrm{b}, \mathrm{c}}$ & $27.9^{\mathrm{a}}$ & $35.5^{\mathrm{c}}$ & $28.0^{\mathrm{a}}$ \\
\hline & 2009 & $35.7^{c}$ & $39.2^{\mathrm{d}}$ & $32.8^{\mathrm{c}}$ & $26.8^{\mathrm{b}}$ & $23.5^{\mathrm{a}}$ & $27.0^{\mathrm{b}}$ \\
\hline \multirow{2}{*}{ Stage I (Flowering) } & 2008 & $112.9^{b}$ & $114.4^{\mathrm{c}}$ & $115.6^{\mathrm{d}}$ & $114.1^{\mathrm{c}}$ & $117.1^{\mathrm{e}}$ & $110.9^{\mathrm{a}}$ \\
\hline & 2009 & 113.0 & 113.0 & 113.0 & 113.0 & 113.0 & 113.0 \\
\hline \multirow[b]{2}{*}{ Stage M (Veraison) } & 2008 & $183.2^{\mathrm{b}}$ & $180.9^{\mathrm{a}}$ & $185.7^{\mathrm{c}}$ & $182.2^{\mathrm{b}}$ & $182.7^{\mathrm{b}}$ & $182.3^{\mathrm{b}}$ \\
\hline & 2009 & $178.1^{\mathrm{b}}$ & $174.1^{\mathrm{a}}$ & $182.5^{c}$ & $176.5^{\mathrm{b}}$ & $177.8^{\mathrm{b}}$ & $172.0^{\mathrm{a}}$ \\
\hline \multirow{2}{*}{ Stage N (Harvest) } & 2008 & 226.0 & 226.0 & 232.0 & 226.0 & 219.0 & 219.0 \\
\hline & 2009 & 217.0 & 217.0 & 229.0 & 217.0 & 217.0 & 220.0 \\
\hline \multirow{2}{*}{ Stage P (Leaf fall) } & 2008 & $267.5^{\mathrm{a}}$ & $268.2^{\mathrm{a}, \mathrm{b}}$ & $273.7^{\mathrm{c}, \mathrm{d}}$ & $269.3^{\mathrm{b}}$ & $274.2^{\mathrm{d}}$ & $272.9^{c}$ \\
\hline & 2009 & $262.1^{\mathrm{a}}$ & $263.6^{\mathrm{a}}$ & $270.3^{\mathrm{b}}$ & $264.0^{\mathrm{a}}$ & $274.7^{c}$ & $271.2^{\mathrm{b}, \mathrm{c}}$ \\
\hline \multirow{2}{*}{ Duration of the cycle } & 2008 & $233.9^{\mathrm{a}}$ & $234.1^{\mathrm{a}}$ & $239.8^{\mathrm{b}, \mathrm{c}}$ & $241.5^{c}$ & $238.3^{\mathrm{b}}$ & $244.9^{d}$ \\
\hline & 2009 & $226.6^{\mathrm{a}}$ & $224.3^{\mathrm{a}}$ & $237.5^{\mathrm{b}}$ & $237.1^{\mathrm{b}}$ & $251.7^{\mathrm{d}}$ & $244.0^{c}$ \\
\hline
\end{tabular}

For the same year, cultivars with the same letter as superscript did not show significant differences among them.

Table IV

Sprouting percentages (\%) of the cultivars

Percentagens de brotaçao das cultivares

\begin{tabular}{|c|c|c|c|c|c|c|c|}
\hline & & Albarín Negro & Mencía & Carrasquín & Verdejo Negro & Godello & Albarín Blanco \\
\hline \multirow{3}{*}{ Sprouting percentage } & 2008 & $95.50^{\mathrm{a}}$ & $93.68^{\mathrm{a}}$ & $94.00^{\mathrm{a}}$ & $94.24^{\mathrm{a}}$ & $92.41^{\mathrm{a}}$ & $93.97^{\mathrm{a}}$ \\
\hline & 2009 & $92.01^{\mathrm{b}}$ & $90.00^{\mathrm{b}}$ & $86.87^{\mathrm{b}}$ & $79.90^{\mathrm{a}}$ & $80.39^{\mathrm{a}}$ & $80.27^{\mathrm{a}}$ \\
\hline & Sig & ns & ns & * & $* * *$ & $* *$ & $* * *$ \\
\hline \multirow{3}{*}{$\begin{array}{c}\text { Global sprouting } \\
\text { percentage }\end{array}$} & 2008 & $191.96^{\mathrm{b}}$ & $185.22^{\mathrm{b}}$ & $159.62^{\mathrm{a}}$ & $187.69^{\mathrm{b}}$ & $180.63^{\mathrm{a}, \mathrm{b}}$ & $189.53^{\mathrm{b}}$ \\
\hline & 2009 & $242.95^{\mathrm{b}}$ & $216.17^{\mathrm{b}}$ & $228.30^{\mathrm{b}}$ & $247.79^{\mathrm{b}}$ & $235.98^{\mathrm{b}}$ & $110.10^{\mathrm{a}}$ \\
\hline & Sig & $* * *$ & * & $* * *$ & $* *$ & $* * *$ & $* * *$ \\
\hline \multirow{3}{*}{$\begin{array}{l}\text { Sprouting percentage of } \\
\text { secondary buds }\end{array}$} & 2008 & $0.00^{\mathrm{a}}$ & $0.00^{\mathrm{a}}$ & $0.83^{\mathrm{a}}$ & $5.08^{\mathrm{b}}$ & $5.17^{\mathrm{b}}$ & $1.86^{\mathrm{a}}$ \\
\hline & 2009 & $10.86^{\mathrm{b}}$ & $10.01^{\mathrm{a} . \mathrm{b}}$ & $9.32^{\mathrm{b}}$ & $10.60^{\mathrm{b}}$ & $18.57^{\mathrm{b}}$ & $1.82^{\mathrm{a}}$ \\
\hline & Sig & $* * *$ & $* *$ & $* * *$ & * & $* * *$ & ns \\
\hline
\end{tabular}

For the same year, cultivars with the same letter as superscript did not show significant differences among them. Sig: interannual significance: ns (not significant); *(0.05); ** (0.01); *** (0.001).

Fertility has a strong varietal component, with fluctuations (Huglin and Schneider, 2003). The drop of temperature at budburst in 2009 lowered the total fertilities and the fertility of spurs for all the cultivars excepting 'Albarín Negro' and 'Carrasquín' that remained stable. 'Albarín Negro' presented the highest potential and real fertility values among all the cultivars, and it underwent an increase of the fertility of watersprouts in 2009. 'Carrasquín' increased the basal buds fertility that year, in contrast to 'Godello' and 'Albarín Blanco' (Tables V and VI). Despite the reports by some authors showing that shoots from basal buds and watersprouts are little fertile or sterile (Hidalgo, 1999; Reynier, 2005), others such as Huglin and Schneider (2003) cite the study by Balthazard that evidenced that watersprouts 
are fruitful. According to our results, although the fertility of the spurs was usually greater, shoots from basal buds and watersprouts were also fertile, even basal shoots of some cultivars presented similar fertility to that of damaged spurs. Real fertility of watersprouts was similar to that of basal buds excepting for 'Albarín Negro' and 'Godello' in 2009 (Table VI).

Table V

Total potential and real fertility of the cultivars

Fertilidade potencial e real total das cultivares

\begin{tabular}{|c|c|c|c|c|c|c|c|}
\hline & & Albarín Negro & Mencía & Carrasquín & Verdejo Negro & Godello & Albarín Blanco \\
\hline \multirow{3}{*}{ Total potential fertility } & 2008 & $1.37^{\mathrm{c}}$ & $1.17^{\mathrm{b}, \mathrm{c}}$ & $0.92^{\mathrm{a}}$ & $1.11^{\mathrm{a}, \mathrm{b}}$ & $1.06^{\mathrm{a}, \mathrm{b}}$ & $1.04^{\mathrm{a}, \mathrm{b}}$ \\
\hline & 2009 & $1.29^{\mathrm{d}}$ & $0.90^{\mathrm{b}, \mathrm{c}}$ & $0.97^{\mathrm{c}}$ & $0.80^{\mathrm{b}, \mathrm{c}}$ & $0.48^{\mathrm{a}}$ & $0.70^{\mathrm{b}}$ \\
\hline & Sig & ns & $* *$ & ns & $* *$ & $* * *$ & $* * *$ \\
\hline \multirow{3}{*}{ Total real fertility } & 2008 & $1.38^{\mathrm{c}}$ & $1.12^{\mathrm{b}, \mathrm{c}}$ & $0.89^{\mathrm{a}}$ & $1.09^{\mathrm{a}, \mathrm{b}}$ & $1.03^{\mathrm{a}, \mathrm{b}}$ & $1.01^{\mathrm{a}, \mathrm{b}}$ \\
\hline & 2009 & $1.25^{\mathrm{d}}$ & $0.87^{\mathrm{c}}$ & $0.92^{\mathrm{c}}$ & $0.74^{\mathrm{b}, \mathrm{c}}$ & $0.45^{\mathrm{a}}$ & $0.61^{\mathrm{b}}$ \\
\hline & Sig & ns & $* *$ & ns & $* * *$ & $* * *$ & $* * *$ \\
\hline
\end{tabular}

For the same year, cultivars with the same letter as superscript did not show significant differences among them. Sig: interannual significance: ns (not significant); * $(0.05)$;** $(0.01)$; ** $(0.001)$.

Table VI

Potential and real fertility of the different types of shoots according to their origin on the vine

Fertilidade potencial e real dos diferentes tipos de pâmpano de acordo com a sua origem na videira

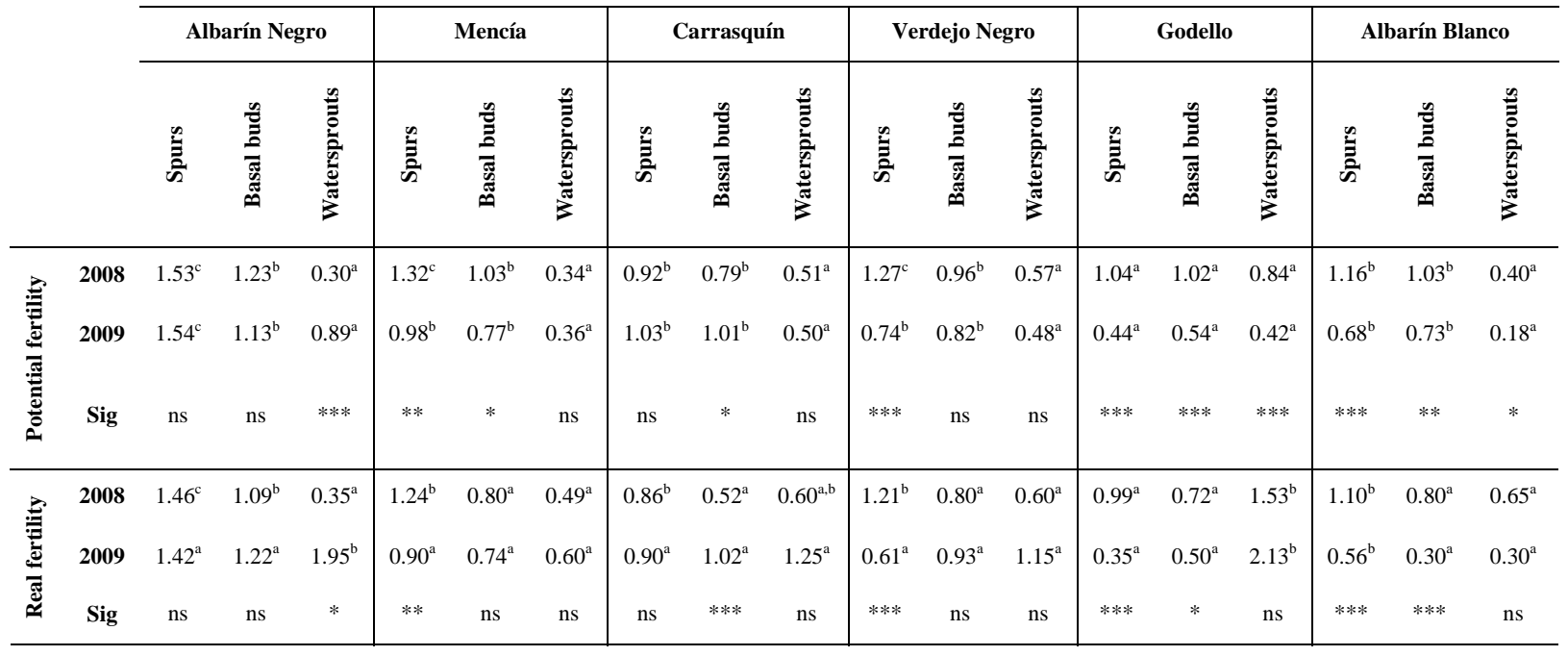

For the same year, types of shoots with the same letter as superscript did not show significant differences among them. Sig: interannual significance: ns (not significant); * (0.05); ** (0.01); *** (0.001).

Results of production and vigor are shown in Table VII. No differences between years were found in total production per vine for the cultivars of the oldest plot ('Mencía' and 'Albarín Negro'). These two cultivars together with 'Albarín Blanco' were the most productive per hectare. Total production per vine of 'Verdejo Negro' was similar in 2008 to that of these three cultivars, whereas 'Carrasquín' was the most productive per vine in 2009. The higher berry production per hectare of 'Albarín Negro', 'Mencía' and 'Albarín Blanco' is due to their higher planting density (Table I), because these plantations are not mechanized, in contrast to the other cultivars. Loureiro and Suárez (2006) determined as the most productive per vine the 'Albarín Negro' cultivar in a study with these same red cultivars and 'Albarín 
Blanco', disposed in several old vineyards. White cultivars and 'Verdejo Negro' suffered an important yield decrease in 2009, caused by the important reduction in the sprouting percentage, the fertility of the spurs, and also the fertility of basal buds in the case of the white cultivars. The damage of spurs is evidenced by an important drop in 2009 of their berry production in 'Verdejo Negro' and 'Godello', 'Albarín Negro' being also affected. In the case of 'Albarín Blanco', the lower production was mainly due to the reduction in the production of basal buds. For every cultivar excepting 'Godello', intravarietal significant differences between the production of spurs, basal buds and watersprouts were found in 2008; however in 2009 the production of basal buds did not show significant differences compared with that of spurs, excepting for the 'Albarín Blanco'. 'Mencía', one of the most productive cultivars, had the heaviest bunch, in agreement with that reported by Loureiro and Suárez (2006, 2007). 'Godello' presented the lowest production and small bunches. Within each cultivar, no significant differences were found when comparing the average weight of the bunches originated from the spurs with that from the basal buds and the watersprouts.

The cultivars of the oldest plot ('Albarín Negro' and 'Mencía') produced less pruning wood per vine, their Ravaz index being higher than those of the other cultivars. However, 'Albarín Blanco' and 'Albarín Negro' presented the highest pruning wood weight per hectare because of their greater planting density. 'Albarín Blanco' is reported by all the grape growers as the most vigorous in terms of pruning wood weight, showing very thick shoots. In a study including the same cultivars excepting 'Albarín Blanco', the lowest Ravaz Index corresponded to 'Verdejo Negro' and 'Godello' because of their low berry production (Loureiro and Suárez, 2007). In 2009 the pruning wood weight per vine significantly increased for all the cultivars.

'Albarín Blanco', 'Verdejo Negro' and 'Mencía' presented the highest berry weight (Table VIII). All the cultivars increased their values for this parameter from 2008 to 2009, this increase being significant in the case of the white cultivars and 'Verdejo Negro'. Hernáez et al (2000) studied the 'Albarín Negro', 'Verdejo Negro' and 'Carrasquín', reporting 'Verdejo Negro' as having the greatest bunch and berry weight. Total acidity and probable alcohol content values in berry of 'Albarín Blanco' (Table VIII) were similar to those previously reported (Santiago et al., 2005; Blanco et al., 2007). Regarding 'Godello', our results for total acidity and probable alcoholic content were consistent with the obtained by Losada and Pariente (1998). Concerning red cultivars, the probable alcoholic content obtained for 'Albarín Negro', 'Carrasquín' and 'Verdejo Negro' was higher than that reported for these three cultivars by Hernáez et al. (2000); however, total acidity of 'Verdejo Negro' was similar. According to these and other previous results (García et al., 2010; Loureiro et al., 2015), 'Verdejo Negro' is characterized by a high value for probable alcoholic content, and together with 'Mencía' by a high $\mathrm{pH}$ and a low total acidity. Total acidity significantly decreased in 2009 for red cultivars whereas $\mathrm{pH}$ significantly increased for all the cultivars excepting 'Godello' and 'Albarín Negro' when compared with the values of 2008. The high acidity of some of these autochthonous cultivars ('Albarín Blanco', ‘Godello', ‘Carrasquín’ and 'Albarín Negro') is relevant because climate change is beginning to affect the ability of cultivars to achieve a balanced ripening, increasing the sugar content and $\mathrm{pH}$, and decreasing acidity and aromas, with the subsequent lack of freshness and problems in the elaboration and conservation of wines (van Leeuwen and Darriet, 2016). 'Albarín Blanco' and 'Albarín Negro' presented the highest values of malic acid. The shikimic acid content has been used as a varietal marker in several studies (Mardones et al., 2005; Tamborra and Esti, 2010), and great differences in their concentrations were noticed among cultivars both years, in agreement with previous studies (García et al., 2010; Loureiro et al., 2015).

The first two discriminant functions obtained by stepwise discriminant analysis explained $87.9 \%$ of the variance. Their projection on a plane allowed the separation of all of the cultivars studied (Figure 2). Ten variables were the most discriminant in the separation: weight of the bunch from shoots from basal buds, harvest and leaf fall dates, total production and pruning wood weight per vine, weight of 100 berries, ${ }^{\circ}$ Brix, and the acids tartaric, malic and shikimic. The horizontal axis is mainly associated with shikimic acid, and in a minor extent with the berry weight, tartaric and malic acids; along this axis, almost all the cultivars are clearly separated, 'Verdejo Negro' placed at the positive side is characterized by a high berry weight and shikimic acid content and low acid malic content; at the negative side, the 'Godello' cultivar is characterized by its very low concentration in shikimic acid and high acid malic content. The vertical axis is related to harvest and leaf fall dates and pruning wood weight, which separates 'Mencía' and 'Albarín Negro' at the negative side, with an earlier leaf fall and low pruning wood weight, and 'Godello' at the positive side, with a later leaf fall and high pruning wood weight. 
Table VII

Production and vigor results

Resultados de produção e vigor

\begin{tabular}{|c|c|c|c|c|c|c|c|c|}
\hline & Parameters & Year & Albarín Negro & Mencía & Carrasquín & Verdejo Negro & Godello & Albarín Blanco \\
\hline \multirow{12}{*}{ 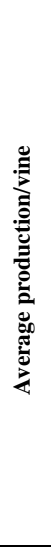 } & \multirow{3}{*}{ Total production/vine (kg) } & 2008 & $1.232^{\mathrm{a}, \mathrm{b}}$ & $1.469^{\mathrm{a}, \mathrm{b}}$ & $0.995^{\mathrm{a}}$ & $1.280^{\mathrm{a}, \mathrm{b}}$ & $0.905^{\mathrm{a}}$ & $1.384^{\mathrm{b}}$ \\
\hline & & 2009 & $1.232^{\mathrm{c,d}}$ & $1.255^{\mathrm{b}, \mathrm{c}, \mathrm{d}}$ & $1.394^{\mathrm{d}}$ & $0.782^{\mathrm{b}}$ & $0.305^{\mathrm{a}}$ & $0.953^{\mathrm{b}, \mathrm{c}}$ \\
\hline & & Sig & ns & ns & $*$ & $* * *$ & $* * *$ & $* * *$ \\
\hline & \multirow{3}{*}{ From spurs (kg) } & 2008 & $0.803^{\mathrm{b}}$ & $0.936^{\mathrm{b}}$ & $0.642^{\mathrm{b}}$ & $0.745^{\mathrm{b}}$ & $0.438^{\mathrm{a}}$ & $0.771^{\mathrm{b}}$ \\
\hline & & 2009 & $0.611^{\mathrm{c}}$ & $0.721^{c}$ & $0.602^{\mathrm{c}}$ & $0.289^{\mathrm{b}}$ & $0.104^{\mathrm{a}}$ & $0.720^{\mathrm{c}}$ \\
\hline & & Sig & $*$ & ns & ns & $* * *$ & $* * *$ & ns \\
\hline & \multirow{3}{*}{ From basal buds (kg) } & 2008 & $0.528^{b}$ & $0.523^{\mathrm{b}}$ & $0.296^{\mathrm{a}}$ & $0.472^{\mathrm{b}}$ & $0.304^{\mathrm{a}}$ & $0.533^{\mathrm{b}}$ \\
\hline & & 2009 & $0.527^{c}$ & $0.464^{\mathrm{b}, \mathrm{c}}$ & $0.667^{c}$ & $0.435^{\mathrm{c}}$ & $0.120^{\mathrm{a}}$ & $0.217^{\mathrm{a}, \mathrm{b}}$ \\
\hline & & Sig & ns & ns & $* * *$ & ns & $* * *$ & $* * *$ \\
\hline & \multirow{3}{*}{ From watersprouts (kg) } & 2008 & $0.045^{\mathrm{a}}$ & $0.068^{\mathrm{a}, \mathrm{b}}$ & $0.057^{\mathrm{a}, \mathrm{b}}$ & $0.076^{\mathrm{a}, \mathrm{b}}$ & $0.167^{b}$ & $0.093^{\mathrm{a}, \mathrm{b}}$ \\
\hline & & 2009 & $0.128^{\mathrm{b}}$ & $0.072^{\mathrm{a}, \mathrm{b}}$ & $0.128^{\mathrm{b}}$ & $0.058^{\mathrm{a}, \mathrm{b}}$ & $0.081^{\mathrm{b}}$ & $0.015^{\mathrm{a}}$ \\
\hline & & Sig & $*$ & ns & * & ns & * & $* * *$ \\
\hline \multirow{2}{*}{\multicolumn{2}{|c|}{ Production/hectare (kg/ha) }} & 2008 & 10,181 & 12,140 & 3,685 & 4,741 & 3,620 & 10,646 \\
\hline & & 2009 & 10,181 & 10,371 & 5,163 & 2,897 & 1,220 & 7,330 \\
\hline \multirow{6}{*}{ 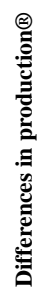 } & From spurs & & c & c & c & c & $\mathrm{b}$ & c \\
\hline & From basal buds & 2008 & $\mathrm{~b}$ & $\mathrm{~b}$ & $\mathrm{~b}$ & $\mathrm{~b}$ & $\mathrm{~b}$ & $\mathrm{~b}$ \\
\hline & From watersprouts & & a & a & a & a & a & a \\
\hline & From spurs & & $\mathrm{b}$ & $\mathrm{b}$ & $\mathrm{b}$ & $\mathrm{b}$ & a & c \\
\hline & From basal buds & 2009 & b & $\mathrm{b}$ & $\mathrm{b}$ & $\mathrm{b}$ & a & $\mathrm{b}$ \\
\hline & From watersprouts & & a & a & a & a & a & $\mathrm{a}$ \\
\hline \multirow{12}{*}{ 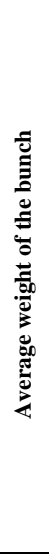 } & \multirow{3}{*}{ From spurs (g) } & 2008 & $111.6^{\mathrm{b}}$ & $169.8^{\mathrm{c}}$ & $128.2^{\mathrm{b}}$ & $103.4^{\mathrm{b}}$ & $69.8^{\mathrm{a}}$ & $103.6^{\mathrm{b}}$ \\
\hline & & 2009 & $89.3^{\mathrm{a}, \mathrm{b}}$ & $214.5^{\mathrm{c}}$ & $118.3^{\mathrm{b}, \mathrm{c}}$ & $90.4^{\mathrm{a}, \mathrm{b}}$ & $65.0^{\mathrm{a}}$ & $118.4^{\mathrm{b}, \mathrm{c}}$ \\
\hline & & Sig & $*$ & ns & ns & ns & ns & ns \\
\hline & \multirow{3}{*}{ From basal buds (g) } & 2008 & $98.7^{\mathrm{b}}$ & $168.1^{\mathrm{c}}$ & $107.3^{\mathrm{a}, \mathrm{b}}$ & $104.5^{\mathrm{b}}$ & $73.7^{\mathrm{a}}$ & $116.7^{\mathrm{b}, \mathrm{c}}$ \\
\hline & & 2009 & $82.4^{\mathrm{b}}$ & $146.6^{\mathrm{c}}$ & $110.0^{c}$ & $79.4^{\mathrm{b}}$ & $51.5^{\mathrm{a}}$ & $145.1^{\mathrm{b}, \mathrm{c}}$ \\
\hline & & Sig & $*$ & ns & ns & $*$ & $* *$ & ns \\
\hline & \multirow{3}{*}{ From watersprouts (g) } & 2008 & $129.6^{\mathrm{a}}$ & $152.3^{\mathrm{a}}$ & $148.9^{\mathrm{a}}$ & $123.3^{\mathrm{a}}$ & $112.3^{\mathrm{a}}$ & $130.7^{\mathrm{a}}$ \\
\hline & & 2009 & $75.3^{\mathrm{a}, \mathrm{b}, \mathrm{c}}$ & $124.4^{\mathrm{a}, \mathrm{b}, \mathrm{c}}$ & $121.8^{c}$ & $65.4^{\mathrm{a}, \mathrm{b}}$ & $58.5^{\mathrm{a}}$ & $92.0^{\mathrm{a}, \mathrm{b}, \mathrm{c}}$ \\
\hline & & Sig & $*$ & ns & ns & $* *$ & $*$ & ns \\
\hline & \multirow{3}{*}{ Model bunch (g) } & 2008 & $191.5^{\mathrm{a}, \mathrm{b}}$ & $315.7^{c}$ & $205.0^{\mathrm{b}}$ & $176.3^{\mathrm{a}, \mathrm{b}}$ & $165.6^{\mathrm{a}}$ & $184.2^{\mathrm{a}, \mathrm{b}}$ \\
\hline & & 2009 & $151.0^{\mathrm{a}}$ & $306.5^{c}$ & $211.0^{\mathrm{b}}$ & $185.5^{\mathrm{a}, \mathrm{b}}$ & $192.0^{\mathrm{a}, \mathrm{b}}$ & $212.5^{\mathrm{b}}$ \\
\hline & & Sig & $*$ & ns & ns & ns & ns & $* *$ \\
\hline \multirow{8}{*}{$\stackrel{\circ}{\circ}$} & \multirow{3}{*}{$\begin{array}{l}\text { Average pruning wood } \\
\text { weight/vine (g) }\end{array}$} & 2008 & $451.6^{\mathrm{b}}$ & $303.7^{\mathrm{a}}$ & $789.5^{\mathrm{c}}$ & $671.2^{\mathrm{c}}$ & $749.2^{\mathrm{c}}$ & $729.5^{c}$ \\
\hline & & 2009 & $543.4^{\mathrm{b}}$ & $388.5^{\mathrm{a}}$ & $1,095.1^{\mathrm{c}}$ & $958.2^{\mathrm{c}}$ & $1,037.1^{\mathrm{c}}$ & $922.5^{c}$ \\
\hline & & Sig & $*$ & $*$ & $* * *$ & $* * *$ & $* * *$ & $* * *$ \\
\hline & \multirow{2}{*}{$\begin{array}{l}\text { Average pruning wood } \\
\text { weight }(\mathrm{kg} / \mathrm{ha})\end{array}$} & 2008 & 3,732 & 2,509 & 2,924 & 2,486 & 2,997 & 5,611 \\
\hline & & 2009 & 4,490 & 3,210 & 4,056 & 3,549 & 4,148 & 7,096 \\
\hline & \multirow{3}{*}{ Ravaz index } & 2008 & $2.9^{c}$ & $4.5^{\mathrm{d}}$ & $1.3^{\mathrm{a}}$ & $1.9^{\mathrm{b}, \mathrm{c}}$ & $1.3^{\mathrm{a}}$ & $2.0^{\mathrm{b}}$ \\
\hline & & 2009 & $3.5^{\mathrm{d}}$ & $5.9^{\mathrm{e}}$ & $1.9^{\mathrm{c}}$ & $1.2^{\mathrm{b}}$ & $0.4^{\mathrm{a}}$ & $1.8^{\mathrm{b}, \mathrm{c}}$ \\
\hline & & Sig & ns & ns & $* * *$ & $* * *$ & $* * *$ & ns \\
\hline
\end{tabular}

Intravarietal differences in average production according to the type of shoot. For the same year, cultivars with the same letter as superscript did not show significant differences among them. Sig: interannual significance: ns (no significant); * $(0.05) ;{ }^{* *}(0.01) ;{ }^{* * *}(0.001)$ 
Table VIII

Weight, global parameters and organic acid contents in berry

Peso, parâmetros globais e conteúdo de ácidos orgânicos em baga

\begin{tabular}{|c|c|c|c|c|c|c|c|}
\hline & & Albarín Negro & Mencía & Carrasquín & Verdejo Negro & Godello & Albarín Blanco \\
\hline \multirow{3}{*}{ Weight 100 berries (g) } & 2008 & $164.07^{\mathrm{a}, \mathrm{b}}$ & $209.94^{c}$ & $175.11^{\mathrm{b}}$ & $221.13^{\mathrm{c}}$ & $159.63^{\mathrm{a}}$ & $212.36^{c}$ \\
\hline & 2009 & $180.41^{\mathrm{a}}$ & $226.7^{b}$ & $190.60^{\mathrm{a}}$ & $259.23^{c}$ & $222.01^{\mathrm{b}}$ & $247.73^{\mathrm{c}}$ \\
\hline & Sig & ns & ns & ns & $*$ & $* * *$ & $* * *$ \\
\hline \multirow{5}{*}{$\begin{array}{c}{ }^{\circ} \text { Brix } \\
\text { (\% vol: probable } \\
\text { alcoholic content) }\end{array}$} & \multirow{2}{*}{2008} & $22.43^{\mathrm{b}}$ & $22.18^{\mathrm{b}}$ & $22.86^{\mathrm{b}}$ & $24.14^{\mathrm{c}}$ & $21.25^{\mathrm{a}}$ & $20.77^{\mathrm{a}}$ \\
\hline & & $(13.04 \%)$ & $(12.83 \%)$ & $(13.31 \%)$ & $(14.22 \%)$ & $(12.22 \%)$ & $(11.88 \%)$ \\
\hline & \multirow{2}{*}{2009} & $21.90^{\mathrm{a}}$ & $21.06^{\mathrm{a}, \mathrm{b}}$ & $23.67^{b}$ & $23.95^{\mathrm{b}}$ & $20.77^{\mathrm{a}}$ & $21.32^{\mathrm{a}}$ \\
\hline & & (12.69\%) & $(12.08 \%)$ & (13.87\%) & $(14.08 \%)$ & $(11.88 \%)$ & (12.29\%) \\
\hline & Sig & $*$ & ns & ns & ns & ns & $*$ \\
\hline \multirow{3}{*}{$\mathbf{p H}$} & 2008 & $3.13^{\mathrm{b}}$ & $3.34^{\mathrm{d}}$ & $3.06^{b}$ & $3.26^{\mathrm{c}}$ & $3.05^{\mathrm{a}}$ & $3.03^{\mathrm{a}}$ \\
\hline & 2009 & $3.15^{\mathrm{a}, \mathrm{b}}$ & $3.49^{c}$ & $3.24^{\mathrm{b}}$ & $3.47^{c}$ & $3.06^{\mathrm{a}}$ & $3.13^{\mathrm{a}}$ \\
\hline & Sig & ns & $* *$ & $* * *$ & $* * *$ & ns & $* *$ \\
\hline \multirow{3}{*}{$\begin{array}{c}\text { Total acidity (g/L } \\
\text { tartaric acid) }\end{array}$} & 2008 & $9.11^{\mathrm{b}}$ & $6.85^{\mathrm{a}}$ & $10.90^{\mathrm{c}}$ & $7.09^{\mathrm{a}}$ & $9.42^{\mathrm{b}}$ & $11.28^{\mathrm{c}}$ \\
\hline & 2009 & $8.15^{\mathrm{b}}$ & $4.91^{\mathrm{a}}$ & $8.01^{\mathrm{b}}$ & $5.88^{\mathrm{a}}$ & $9.56^{\mathrm{c}}$ & $10.33^{\mathrm{d}}$ \\
\hline & Sig & $*$ & $* *$ & $* *$ & $* * *$ & ns & ns \\
\hline \multirow{3}{*}{ Tartaric acid (g/L) } & 2008 & $6.3^{\mathrm{a}}$ & $6.3^{\mathrm{a}}$ & $6.6^{\mathrm{a}}$ & $5.8^{\mathrm{a}}$ & $6.6^{\mathrm{a}}$ & $6.5^{\mathrm{a}}$ \\
\hline & 2009 & $4.8^{\mathrm{a}}$ & $4.4^{\mathrm{a}, \mathrm{b}}$ & $4.6^{\mathrm{a}}$ & $5.2^{\mathrm{a}}$ & $7.7^{\mathrm{c}}$ & $7.1^{\mathrm{b}, \mathrm{c}}$ \\
\hline & Sig & $* *$ & $*$ & $* * *$ & $*$ & $*$ & $* *$ \\
\hline \multirow{3}{*}{ Malic acid (g/L) } & 2008 & $3.9^{\mathrm{b}}$ & $3.1^{\mathrm{a}}$ & $4.2^{\mathrm{b}}$ & $2.5^{\mathrm{a}}$ & $3.0^{\mathrm{a}}$ & $4.9^{c}$ \\
\hline & 2009 & $3.7^{c}$ & $2.2^{\mathrm{a}}$ & $3.1^{\mathrm{b}}$ & $2.2^{\mathrm{a}}$ & $3.2^{\mathrm{b}}$ & $4.4^{\mathrm{d}}$ \\
\hline & Sig & ns & $*$ & $*$ & ns & ns & ns \\
\hline \multirow{3}{*}{ Citric acid (g/L) } & 2008 & $0.2^{\mathrm{a}, \mathrm{b}}$ & $0.2^{\mathrm{a}}$ & $0.2^{\mathrm{a}, \mathrm{b}}$ & $0.2^{\mathrm{b}}$ & $0.2^{\mathrm{a}, \mathrm{b}}$ & $0.3^{c}$ \\
\hline & 2009 & $0.2^{\mathrm{b}}$ & $0.2^{\mathrm{a}}$ & $0.2^{\mathrm{a}}$ & $0.3^{\mathrm{b}}$ & $0.3^{\mathrm{c}}$ & $0.3^{\mathrm{c}}$ \\
\hline & Sig & $*$ & $* *$ & ns & $* * *$ & $*$ & ns \\
\hline \multirow{3}{*}{ Shikimic acid (mg/L) } & 2008 & $13.2^{\mathrm{b}}$ & $19.7^{\mathrm{b}}$ & $73.5^{\mathrm{c}}$ & $63.9^{c}$ & $6.5^{\mathrm{a}}$ & $59.6^{\mathrm{c}}$ \\
\hline & 2009 & $5.1^{\mathrm{a}, \mathrm{b}}$ & $9.3^{b}$ & $34.0^{c}$ & $49.0^{c}$ & $3.5^{\mathrm{a}}$ & $47.5^{c}$ \\
\hline & Sig & $* * *$ & $* *$ & $* *$ & $*$ & $*$ & $* * *$ \\
\hline
\end{tabular}

For the same year, cultivars with the same letter as superscript did not show significant differences among them. Sig: interannual significance: ns (no significant); $*(0.05) ; * *(0.01) ; * * *(0.001)$.

\section{CONCLUSIONS}

In a changing wine market, focused in the last years to uncommon wines, with a differential component of geographic origin and cultivar, Asturian wines represent an interesting option for consumers, eager of original products. An added value is the acidic potential of some of the cultivars studied, such as 'Albarín Blanco', 'Godello', 'Albarín Negro' and 'Carrasquín', a feature of high interest in the present context of global warming. Among the cultivars evaluated,' Albarín Blanco' and 'Verdejo Negro' had an early budburst, so these cultivars are more susceptible to be damaged by frost. 'Albarín Negro' and 'Mencía' presented the shortest vegetative cycle, 'Carrasquín' being the last cultivar to get ripen. The shoots from basal buds and watersprouts showed to be fertile, 'Albarín Negro' presenting the highest fertility values. The cultivars whose vines were older, 'Albarín Negro' and 'Mencía', presented the best vegetative equilibrium, while the young vines exhibited an excess of vigor. 'Verdejo Negro' presented a greater probable alcoholic content; this cultivar, together with 'Mencía', showed the lowest total acidity values and highest $\mathrm{pH}$. Further studies on wine are essential to complete the knowledge of these cultivars. 


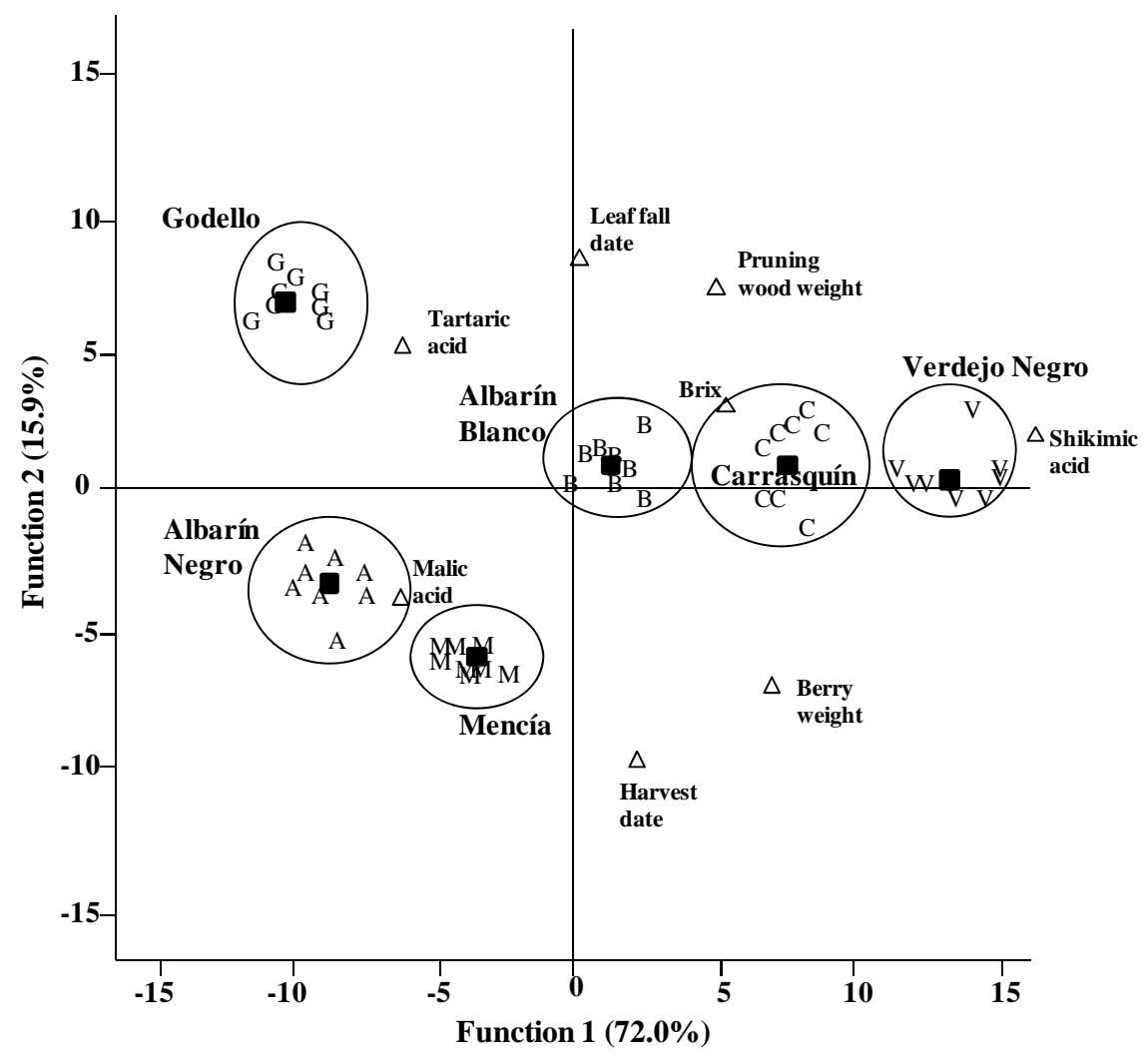

Figure 2. Projection on the plane of the two first discriminant functions ( group centroid)

Projeção no plano das duas primeiras funções discriminantes ( centroide do grupo)

\section{ACKNOWLEDGMENTS}

Authors thank the collaboration of the owners of the vineyards of the study, José $\mathrm{M}^{\mathrm{a}}$ Martínez Parrondo and José Luis Álvarez Marqués. P. Moreno-Sanz is

\section{REFERENCES}

Albuquerque M.V., Yuste J.R., Rubio J.A., Yuste J., 2006. Descripción y caracterización agronómica de 28 variedades tintas de vid en Castilla y León. 196 p. Ed. Instituto Tecnológico Agrario de Castilla y León, Valladolid, Spain.

Baggiolini M., 1952. Les stades repères dans le développement annuel de la vigne et leur utilisation pratique. Rev. romande Agric. Vitic. Arboric., 8, 4-6.

Blanco P., Losada A., Orriols I., 2007. Potencial enológico de Branco Lexítimo y Agudelo. VinoTeQ, 37, 16-19.

BOPA, Boletín Oficial del Principado de Asturias, $\mathrm{n}^{\circ}$ 287, 12/12/2008 (2008), Resolución de 19 de noviembre de 2008, de la Consejería de Medio Ambiente y Desarrollo Rural, por la que se reconoce la denominación "Vino de Calidad de Cangas". indebted to the National Institute of Agronomic and Food Research (INIA), and M. D. Loureiro to the INIA and the European Social Fund for financial support. The cooperation of Dr. Picinelli for her critical review of manuscript is deeply acknowledged.

https://sede.asturias.es/portal/site/Asturias/menuitem.1003733838d b7342ebc4e191100000f7/?vgnextoid=d7d79d16b61ee010 VgnVC M1000000100007fRCRD\&fecha=12/12/2008\&refArticulo=2008 22844

Boulton R.B., Singleton V.L., Bisson L.F., Kunkee R.E., 1999. Principles and Practices of Winemaking. 620 p. Springer Ed., New York.

Cortizo T., González J.M., González J., Vega F., 2008. El vino de la Tierra de Cangas. 239 p. Tragaluz Fotografía Ed., Oviedo, Spain.

Cunha J., Zinelabidine L. H., Teixeira-Santos M., Brazao J. Fevereiro P., Martínez-Zapater J. M., Ibáñez J., Eiras-Dias J. E., 2015. Grapevine cultivar 'Alfrocheiro' or 'Bruñal' plays a primary role in the relationship among Iberian grapevines. Vitis, 54 (Special Issue), 59-65. 
Dobrei A., Dobrei A.G., Nistor E., Iordanescu O.A., Sala F., 2015. Local Grapevine Germplasm from Western of Romania - an Alternative to Climate Change and Source of Typicity and Authenticity. Agric. \& Agric. Sci. Proc., 6, 124-131.

Dry P.R., Coombe B.G., 2004. Viticulture. Volume 1: Resources. $2^{\text {nd }}$ ed. 255 p. Winetitles, Australia.

Feo F., 1986. El viñedo en Asturias: cultivo marginal en vías de extinción. Bol. Inst. Estud. Astur., 118, 589-610.

Gago P., Santiago J.L., Boso S., Alonso-Villaverde V., Martínez, M.C., 2009. El comportamiento agronómico del Albarín Blanco. Sevi, 3284, 2662-2667.

García A., Loureiro M.D., Fernández N., Fernández O., MorenoSanz P., Picinelli A., Suárez, B., 2010. Estudio enológico de variedades minoritarias blancas de vid del Principado de Asturias. In: Proc. VII Foro mundial del vino. Logroño, Spain.

Hernáez J.L., Rodríguez B., Losada A., González J.M., Rúa P., 2000. Características enológicas de tres variedades tintas de Asturias (Albarín Negro, 'Carrasquín', Verdejo Tinto). Sevi, 2836, 4550-4554.

Hidalgo L., 1999. Tratado de Viticultura General, $2^{\text {nd }}$ ed. 1172 p. Mundi-Prensa Ed., Madrid.

Huglin P., Schneider C., 2003. Biologie et écologie de la vigne, $2^{\text {nd }}$ ed. 370 p. Ed. Lavoisier Tec \& Doc, Paris.

Iorizzo M., Macciola V., Testa B., Lombardi S.J., De Leonardis A., 2014. Physicochemical and sensory characteristics of red wines from the rediscovered autochthonous Tintilia grapevine grown in the Molise region (Italy). Eur. Food Res. Technol., 238, 1037-1048.

Jones G.V., Davis R.E., 2000. Climate Influences on Grapevine Phenology, Grape Composition, and Wine Production and Quality for Bordeaux, France. Am. J. Enol. Vitic., 51, 249-261.

Losada M.M., Pariente M.V., 1998. Características enológicas de las variedades Albariño, Dona Branca, ‘Godello’ y Treixadura. Sevi, 2694, 994 - 998.

Loureiro M.D., Moreno-Sanz P., García A., Fernández O., Fernández N., Suárez B., 2016. Influence of rootstock on the performance of the Albarín Negro minority grapevine cultivar. Sci. Hort., 201, 145-152.

Loureiro M.D., Moreno-Sanz P., Suárez B., 2015. Ensayo de portainjertos en variedades de vid de Asturias. 92 p. SERIDA Ed., Asturias, Spain.

Loureiro M.D., Suárez B., 2006. Recuperación de la viticultura en el Principado de Asturias. Tecnol. Vino, 30, 34-40.

Loureiro M.D., Suárez B., 2007. Parámetros agronómicos y enológicos de variedades cultivadas en el Principado de Asturias. In:Proc. XXVIII Jorn. Vitic. Enol.Tierra de Barros. Almendralejo. Spain, 283-292.

Maletic E., Kontic J.K., Preiner D., Jeromel A., Patz C-D., Dietrich H., 2009. Anthocyanin profile and antioxidative capacity of some autochthonous Croatian red wines. J. Food Agric. Environ., 7, 4851.

Mardones C., Hitschfeld A., Contreras A., Lepe K., Gutiérrez L., Von Baer D., 2005. Comparison of shikimic acid determination by capillary zone electrophoresis with direct and indirect detection with liquid chromatography for varietal differentiation of red wines. J. Chromatogr. A, 1085, 285 - 292.
Martín J.P., Arranz C., Castro I.D., Yuste J., Rubio J.A., PintoCarnide O., Ortiz J.M., 2011. Prospection and identification of grapevine varieties cultivated in north Portugal and northwest Spain. Vitis, 50, 29-33.

Mattheou A., Stavropoulos N., Samaras S., 1995a. Studies on table grape germplasm grown in Northern Greece. I. Maturity time, bunch characteristics and yield. Vitis, 34, 155-158.

Mattheou A., Stavropoulos N., Samaras S., 1995b. Studies on table grape germplasm grown in Northern Greece. II. Seedlessness, berry and must characteristics. Vitis, 34, 217- 220.

Merkouropoulos G., Michailidou S., Alifragkis A., Zioziou E., Koundouras S., Argiriou A., Nikolaui N., 2015. A combined approach involving ampelographic description, berry oenological traits and molecular analysis to study native grapevine varieties of Greece. Vitis, 54 (Special Issue), 99-103.

Milella R.A., Pisani R., Mastrofrancesco L., Alba V., Giannandrea M.A., Gasparro M., Caputo A.R., 2016. Phenolic characterization and antioxidant capacity of ten autochthonous vines grown in southern Italy. In: Proc. $39^{\text {th }}$ World Congress of Vine and Wine, Bento Goncalves, Brazil. Office International de la Vigne et du Vin, BIO Web of Conferences, 7 (Art. 01019).

Muñoz G., Benito A., Gaforio L., García S., Cabello F., 2010. Principales estados fenológicos de las variedades españolas de vinificación. Adaptación a las zonas vitícolas del país. Enovitic., 6, $4-9$.

OIV, 2008. $2^{\text {nd }}$ Edition of the OIV descriptor list for grape cultivars and Vitis species. http://www.oiv.int/public/medias/2274/code-2eedition-finale.pdf

Orriols I., Rego F., Soto E., Vázquez I., Rego X., Rey P., Losada A., 2004. Aspectos característicos de variedades tintas de Galicia. In: $19^{a}$ Reunión del Grupo de trabajo de experimentación en viticultura y enología. Galicia, Spain. http://mediorural.xunta.gal/fileadmin/arquivos/investigacion/evega/ p_d45.pdf

Picinelli A., Suárez B., Moreno J., Rodríguez R., Caso-García L.M., Mangas J.J., 2000. Chemical characterization of Asturian cider. J. Agric. Food Chem., 48, 3997-4002.

Reynier A., 2005. Manual de Viticultura, $6^{\text {th }}$ ed. 497 p. MundiPrensa Ed., Madrid.

Santiago J.L., Boso S., Vilanova M., Martínez M.C., 2005. Characterisation of cv. Albarín Blanco (Vitis vinifera L.). Synonyms, homonyms and errors of identification associated with this cultivar. J. Int. Sci. Vigne Vin, 39, 57-65.

Smart R., Robinson M., 1991. Sunlight into wine. A handbook for winegrape canopy management. 88 p. Winetitles Ed. New Zealand.

Tamborra P., Esti M., 2010. Authenticity markers in Aglianico, Uva di Troia, Negroamaro and Primitivo grapes. Anal. Chim. Acta, 660, 221-226.

van Leeuwen C., Darriet P., 2016. The Impact of Climate Change on Viticulture and Wine Quality. J. Wine Econ., 11, 150-167.

Vilanova M., Masa A., Tardaguila J., 2009. Evaluation of the aroma descriptors variability in Spanish grape cultivars by a quantitative descriptive analysis. Euphytica, 165, 383-389.

Winkler A.J., Cook J.A., Kliewer W.M., Lider L.A., 1974. General Viticulture. $2^{\text {nd }}$ Ed. 710 p. University of California Press. 


\section{SUPPLEMENTARY MATERIAL:}

\section{Definitions of the sprouting and fertility parameters}

Sprouting percentage: number of buds count sprouted divided by the number of nodes left in the pruning.

Global sprouting percentage: number of the total shoots grown -from spurs, from basal buds and watersproutsdivided by the number of nodes left in the pruning.

Sprouting percentage of the secondary buds in spurs: number of the secondary shoots divided by the number of nodes left.

Potential fertility of the spurs: number of bunches from spurs divided by the number of sprouted nodes.

Potential fertility of the shoots from basal buds: number of bunches in this kind of shoots divided by the number of shoots from basal buds.

Potential fertility of watersprouts: number of bunches from watersprouts divided by the number of watersprouts.

Total potential fertility: number of the total bunches in the vine divided by the total number of shoots - from spurs, from basal buds and from watersprouts.

Real fertility of the spurs: number of bunches located in shoots from the spurs divided by the number of nodes left.

Real fertility of the shoots from basal buds: number of bunches in this kind of shoots divided by the number of bases of the spurs observed.

Real fertility of watersprouts: number of bunches of watersprouts divided by the number of vines sampled.

Total real fertility: number of bunches per vine divided by the number of buds per vine -nodes left in spurs, shoots from basal buds and watersprouts. 